below the horizon corresponded with that of the moon in the west above the horizon.

"These bands or shoots are more or less numerous, bright, and persistent ; some have been observed in the evening, fortyfive minutes after sunset, and in September, i 876, I saw them appear with the first break of day. They are evidently movable in the sky, and there is no doubt that they are due to cumuli floating about the horizon, below or above, through which the light of the sun is sifted and split; they are, in fact, nothing else than the shadows of the clouds in the faint white or rosy tint of the twilight. According as the clouds before the sun are more or less compact or loose, the bands may be blue, white, or red. More than once also have I seen the sky half white and balf blue, the separation of the two colours being plainly perceivable, and Venus shining brilliantly in the blue sky close to that limit, whilst it would probably have been almost invisible through the milky sky hard by."

Any one who gazes for the first time at this beautiful phenomenon cannot help wondering and acknowledging it to be greatly different from anything to be seen elsewhere. The celebrated Jesuit, Father Bouvet, an old missionary to China, witnessed the phenomenon when on his way from China to Europe as envoy of the great Emperor Kang-hi, in the year 1693; the relation of the voyage (du Halde, vol. i., I 755) gives the following account of his observations :-

" 25 Juillet, 1693 . - Ce jour-là, environ un quart d'heure avant le lever du soleil, je vis dans le ciel un phénomène que je n'aj jamais vu et dont je n'ai point oui parler en France, quoiqu'il soit fort ordinaire en Otient, surtout à Siam et à la Chine ; car je l'ai observe distinctement plus de vingt fois, tantôt le matin, tantôt le soir, dans chacun de ces deux Royaumes, sur mer et sur terre, et même à Péking.

"Ce phénomène n'est autre chose que certains demi-cercles d'ombre et de lumière que paraissent se terminer et s'unir dans deux points opposés du Ciel, savoir d'un côté dans le centre du Soleil, et de l'autre dans le point qui est diamétralement opposé à celui-là. Comme ces demi-cercles sont tous terminés en pointe, tant en Orient qu'en Occident, c'est-à-dire vers les points opposés de leur réunion et qu'ils vont en s'élargissant uniformément vers le milieu du Ciel à mesure qu'ils s'éloignent de l'horizon, ils ne ressemblent pas mal pour leur figure aux Maisons Célestes, de la manière dont on les trace sur les Globes, à cela près seulement que ces Zônes d'ombre et de lumière sont ordinairement fort inégales pour la largeur et qu'il arrive souvent qu'il y a de l'interruption entr'elles, surtout lorsque le phénomène n'est pas bien formé.

"Toutes les fois que je l'ai observé, et je l'ai vu quatre fois différentes dans ce voyage en moins de quinze jours, $\mathrm{j}$ 'ai toujours remarqué que le temps était extrêmement chaud, le ciel chargé de vapeurs, avec une disposition au tonnerre et qu'un gros nuage épais entr'ouvert était vis-à-vis du Soleil. Ce phénomène semble pour la figure fort différent de ces longues traces d'ombre et de lumière qu'on voit souvent le soir et le matin dans le ciel aussi bien en Europe qu'ailleurs et auxquelles leur figure pyramidale a fait donner le nom de verges. Si l'on demande pour quelle raison ce phénomène paraît plutôt en Asie qu'en Europe et en été que dans les autres saisons, il me semble qu'on pourrait en attribuer la cause à la nature des terres de l'Asie, qui étant pour la plupart beaucoup plus chargées de nitre que celles d'Europe, remplissent l'atmosphère, surtout en été, et lorsque le soleil a plus de force pour les élever, d'exhalaisons nitreuses, lesquelles étant répandues également dans l'air, les rendent plus propres à réfléchir la lumière et par conséquent à former le météore."

The phenomenon described by the old Jesuit astronomer is undoubtedly the same I have witnessed hundreds of times at Zi-ka-Wei. He evidently considers it as different from any hitherto observed atmospheric phenomenon; but his explanation is tainted with the false science of his time. It is quite certain that the phenomenon is due to the atmospheric vapour, but I am rather at a loss to give a more satisfactory explanation. The dispersion of the direct rays of the sun into the minute drops resulting from a partial but wide-spreading condensation of the aqueous vapour in the upper strata of the air, might account for the milky or roseate appearance of the sky at morning and evening time. Besides, the interposition of a light cloud in the way of the sun's rays does not impair the transparency of the drops, and the blue sky may be visible. Now, in the morning and evening the rays of the sun are almost parallel with the horizon; they traverse the whole expanse of the sky, and their apparent convergence on the both sides is only due to the same optical illusion which shows us the two rails of a railway track or the walls of a tunnel as converging.

Let this explanation be worth $\mathrm{what}$ it may, the fact in inself is interesting, and I would beg you, Sir, to notice it in NATURE, dealing, however, with this long communication as you may deem proper. Marc Dechevrens

$\mathrm{Zi}$-ka-Wei Observatory, near Shanghai, (China), August 28

\section{Habits of Scypho-Medusæ}

THE communications to NATURE of Mr. Archer (vol. xxiv. p. 307), and of Mr. Alexander Agassiz (vol. xxiv. p. 509), on the subject of Medusæ lying upon the bottom with their tentacles upw ard, lead me to forward some observations which I made on a similar habit of Medusæ in the island of Simbo, one of the Solomon Islands. The Medusa in question frequents a small mangrove swamp, which lies inclosed in the low point that forms the south shore of the anchorage. Numbers of these animals of a large and dirty-white colour were lying lazily on the mud at the bottom of the water, which varied in depth from one to three feet, with their umbrellas lowermost, and a magnificent mass of arborescent tentacles well displayed. When one of them was disturbed and turned over with a stick, it immediately began to contract the umbrella, until, after swimming a short distance, it resumed its former position on the bottom, of tentacles upward. The dark mud which formed the bottom of the swamp was composed of decayed vegetable matter-low confervoid growths, and a few infusoria and living diatoms. But I invariably observed, after raising several of these Medusæ from the bottom, that a layer of white sand covered over the place where each had lain, its light colour forming a marked contrast with the dark mud around. The form of these patches of sand corresponded with the outline of the animal; but when the Medusa lay in its usual position, the umbrella completely concealed them from view. The sand was sometimes fine, at other times coarse, and was derived from the coral and trachytic rocks in the vicinity, with occasionally fragments of shells intermingled. The sand did not adhere to the surface of the umbrella.

The Medusæ measured generally some eight or nine inches across the umbrella, and appeared to belong to the Rhizostomidæ.

H. B. GUPPY

H.M.S. Lark, St. Christoval, Solomon Islands, June 29

\section{Prof, Owen on Primitive Man}

IN the first number of Longman's Magazine Prof. Owen criticises an article of mine on Prinitive Man, in the Fortnightly Review. In doing so, he quotes some words from my article, which are there given as a quotation from Prof. Schaafhausen. He proceeds to make them the text of his paper, as though the opinions expressed in them were my own. On the question at issue-the Neanderthal skull-I am not competent to form any personal opinion; I merely abstracted the opinions of Rolleston and schaafhausen. Prof. Owen would hardly have spoken in the same lofty magisterial tone bad he attributed those opinions to their real authors, whose reputation can take care of itself. The respect I feel for Prof. Owen's work makes me deeply regret the necessity for this explanation; but I cannot allow him to quote as mine words which I placed between inverted commas, attributing them at the same time to their real author.

GRANT ALIEN

\section{Magnetic Arrangement of Clouds}

THERE is a curious arrangement of clouds which, though seen my:elf for the first time this year, may doubtless have been observed by others, though I have never seen it referred to anywhere. Light clouds of the cirrus formation apparently at great elevations range themselves round two poles-one about in the direction of the magnetic north pole, and the other in that of the south. The space between the two poles is filled more or less completely by wispy cirri. The exact point where the various threads or wisps should form themselves into a pole I have never been able to clearly see, owing to the dense stratum of vapour which even on the clearest day accumulates at the horizon. On Sunday, October 29, the arrangement above noticed was remarkably distinct in the afternoon.

C. H. ROMANES Worthing 